\title{
ANALISIS PENERAPAN AKUNTANSI PERTANGGUNGJAWABAN TERHADAP PERILAKU BIAYA PADA PERUSAHAAN START UP
}

\author{
Yana Aida Fitriyah ${ }^{1 *}$, Hilda Octavana Siregar ${ }^{2}$ \\ ${ }^{1 *}$ Departemen Ekonomika dan Bisnis Sekolah Vokasi, Universitas Gadjah Mada \\ email: yanaaida99@mail.ugm.ac.id \\ ${ }^{2)}$ Departemen Ekonomika dan Bisnis Sekolah Vokasi, Universitas Gadjah Mada \\ email: hilda.octavana.s@mail.ugm.ac.id
}

\begin{abstract}
Start-up companies still need investment and cost control to maintain the company's survival. The application of responsibility accounting can improve efficiency in companies, especially in the aspect of cost. PT WII is a start up company engaged in Artificial Intelligence and the Internet of Things. The author conducted research on this company with the aim of whether the implementation of responsibility accounting as a cost control tool at PT WII has functioned well according to the terms and elements of responsibility accounting. This research uses qualitative and quantitative approaches. The research data were obtained from observations, interviews and documentation. The analytical method of this research is descriptive analysis by comparing the application of responsibility accounting and comparing the budget and cost realization. The results of research at PT WII, namely the company has not implemented accountability accounting properly, this can be known by the existence of several accountability accounting requirements that have not been met. The company also has not implemented cost control well, this can be seen from the still cost deviation to the cost budget. The company should separate the controlled costs, improve the account code system, update the performance standard indicators, follow up on accountability reports, and reinforce awards.
\end{abstract}

Keywords: Responsibility Accounting; Cost Control; Budget and Cost Realization.

\begin{abstract}
ABSTRAK
Perusahaan start up masih membutuhkan investasi serta pengendalian biaya untuk menjaga kelangsungan hidup perusahaan. Penerapan akuntansi pertanggungjawaban dapat meningkatkan efisiensi pada perusahaan terutama pada aspek biaya. PT WII merupakan perusahaan start up yang bergerak di bidang Artificial Intelligence dan Internet Of Things. Penelitian ini bertujuan menganalisis penerapan akuntansi pertanggungjawaban sebagai alat pengendalian biaya pada PT WII telah berfungsi dengan baik sesuai syarat dan unsur akuntansi pertanggungjawaban. Penelitian ini menggunakan pendekatan metode campuran kualitatif dan kuantitatif. Data penelitian diperoleh dari hasil observasi, wawancara dan dokumentasi. Metode analisis dari penelitian ini adalah analisis deskriptif dengan membandingkan antara penerapan akuntansi pertanggungjawaban pada perusahaan dengan teori akuntansi pertanggungjawban serta membandingkan antara anggaran dan realisasi biaya. Hasil penelitian bahwa perusahaan belum menerapkan akuntansi pertanggungjawaban dengan baik, hal ini dapat diketahui dengan adanya beberapa syarat-syarat akuntansi pertanggungjawaban yang belum terpenuhi. Perusahaan juga belum melaksanakan pengendalian biaya dengan baik, hal ini dapat dilihat dari masih adanya penyimpangan biaya terhadap anggaran biaya. Sebaiknya perusahaan melakukan pemisahan biaya terkendali, memperbaiki sistem kode rekening, memperbarui indikator standar kinerja, menindaklanjuti laporan pertanggungjawaban, dan mempertegas pemberian penghargaan.
\end{abstract}

Kata Kunci: Akuntansi Pertanggungjawaban; Pengendalian Biaya; Anggaran dan Realisasi Biaya 


\section{PENDAHULAN}

Pendahuluan Pada zaman yang serba modern ini, perkembangan teknologi berubah sangat cepat. Seiring dengan perkembangan tersebut, berbagai bidang juga mengalami dampak dari perubahan zaman tidak terkecuali bidang ekonomi. Perekonomian di Indonesia saat ini juga mengalami perubahan yang pesat, hal ini menunjukkan ekonomi Indonesia membutuhkan inovasi sebagai sumber pertumbuhan ekonomi yang berkelanjutan. Ekonomi kreatif-yang merupakan ekonomi dengan berlandaskan pada inovasi dan kreasi - menjadi harapan Indonesia untuk meningkatkan daya saing perusahaan di pasar domestik maupun internasional.

Perusahaan start up yang muncul di dunia ekonomi kreatif menunjukkan bahwa daya saing perusahaan Indonesia memiliki prospek yang cukup cerah. Setiap perusahaan akan melakukan berbagai cara untuk mencapai tujuannya termasuk dalam hal kestabilan ekonomi. Dalam usaha untuk mencapai tujuan tersebut, perusahaan harus mempersiapkan strategi dengan matang yang memerlukan kerjasama dari semua komponen yang ada dalam perusahaan tersebut. Kerjasama dari setiap komponen biasanya diatur dalam susunan struktur organisasi. Di dalam struktur organisasi, memuat hal-hal yang berkaitan dengan tugas, wewenang, dan tanggung jawab bagi setiap komponen perusahaan.

Berdasarkan hasil Listing Sensus Ekonomi 2016(SE2016) usaha start up Indonesia yang berdiri setelah tahun 2014 ditemukan sebesar 19,79\%. Berdasarkan database start up yang dilakukan Badan Ekonomi Kreatif Indonesia tahun 2018, terdapat 992 start up di Indonesia yang menunjukkan daerah terbanyak diraih oleh Jabodetabek sebesar 522, disusul oleh Sumatera sebesar 115, kemudian Jawa Timur sebesar 113, kemudian Daerah Istimewa Yogyakarta sebesar 54, Jawa Barat sebesar 44, Sulawesi sebesar 34, Bali dan NTB sebesar 32, Jawa tengah sebesar 30, Kalimantan sebesar 24, dan domisili tidak diketahui sebesar 24 .

Terkait tujuan untuk mencapai kestabilan ekonomi, perusahan berlomba-lomba untuk mendapatkan investor kaitannya dengan pemberian modal kepada perusahaan tersebut. Perusahaan start up masih memerlukan investasi sedangkan biaya operasional perusahaan masih bernilai besar. Oleh karena itu, diperlukan pengendalian biayabiaya yang kurang efektif dengan menerapkan akuntansi pertanggungjawaban.

Menurut Hansen \& Mowen (2009:558), Akuntansi pertangungjawaban merupakan sebuah sistem akuntansi yang disusun untuk mengukur hasil yang diharapkan atau dianggarkan. Akuntansi pertanggungjawaban terdiri dari 4 karakteristik, yaitu penetapan tanggung jawab, penentuan ukuran kinerja, evaluasi/penilaian kinerja, dan pemberian penghargaan/hukuman. Jadi akuntansi pertanggungjawaban merupakan bagian dari sistem akuntansi manajemen di mana informasi yang dihasilkan adalah informasi yang mengacu pada pusat pertanggungjawaban dalam perusahaan.

Akuntansi pertanggungjawaban memudahkan pimpinan dapat memantau dan mengatur secara langsung segala aktivitas dan masalah yang ada di perusahaan. Pimpinan perusahaan memberikan garis wewenang dan tanggung jawab kepada pimpinan yang tingkatnya berada di bawahnya. Pusat pertanggungjawaban dibentuk dari wewenang dan tanggung jawab yang telah diberikan dan tugasnya mengendalikan berbagai bagian yang berhubungan dengan tanggung jawab tersebut. Salah satu pusat pertanggungjawaban yang termasuk dalam akuntansi pertanggungjawaban adalah pusat biaya (cost center). Pertanggungjawaban yang dilakukan adalah bagaimana manajer dapat mengendalikan biaya. Informasi ini diharapkan dapat membantu perusahaan dalam menilai kinerja dari pusat 
pertanggungjawaban sehingga keputusan yang diambil lebih akurat. Oleh karena itu, dilakukan penelitian pada PT WII untuk mengetahui pentingnya akuntansi pertanggungjawaban kaitannya dengan pengendalian biaya perusahaan

PT WII merupakan perusahaan start up berbentuk perseroan terbatas di bidang teknologi dan informasi dengan fokus yang kuat menghadirkan teknologi masa depan untuk dipresentasikan melalui penelitian dan pengembangan. PT WII yang didirikan pada 8 September 2018 menawarkan produk dan layanan teknologi inovatif demi tercapainya kepuasan pelanggan. Beberapa produk PT WII seperti Widya Smart Speaker, Widya Doctor (Health ATM), dan Telemetry Tractor.

PT WII mempunyai struktur organisasi yang sudah jelas garis wewenang dan tanggung jawabnya. Perusahan ini memiliki 4 departemen yang terdiri dari departemen akuntansi dan keuangan, departemen personalia, departemen pemasaran, serta departemen penelitian dan pengembangan. Departemen tersebut terbagi menjadi 8 divisi yang terdiri dari Hardware, Back End, Front End, Business Development, Recognition, Mechanical, Finance, Accountant, Human Resource Development, dan Public Relation. Departemen yang menjadi pusat pertanggungjawaban biaya adalah departemen penelitian dan pengembangan yang terdiri dari 5 divisi, yaitu Mechanics, Recognition, Hardware, Front End dan Back End.

Dalam penelitian ini lebih berfokus pada penerapan akuntansi pertanggungjawaban di PT WII. Akuntansi pertanggungjawaban yang baik dapat dilihat dari empat unsur, yaitu penetapan tanggung jawab, penentuan ukuran kinerja, dan pemberian penghargaan dan hukuman. Pada kenyataanya, PT WII masih terdapat masalah seperti tidak menggolongkan biaya ke dalam biaya yang dapat dikendalikan dan tidak dapat dikendalikan, sehingga penyimpangan yang mungkin terjadi tidak dapat ditentukan siapa dan divisi mana yang harus bertanggung jawab atas penyimpangan tersebut.

Berdasarkan uraian dan permasalahan di atas, dapat diketahui bahwa akuntansi pertanggungjawaban mempunyai peranan penting dalam pengendalian biaya perusahaan. Oleh karena itu, penulis mencoba meneliti seberapa besar peranan akuntansi pertanggungjawaban terhadap pengendalian biaya pada PT WII.

\section{KAJIAN LITERATUR}

\section{Biaya}

Biaya menurut Hansen dan Mowen (1997:36) adalah kas atau ekuivalen kas yang dikeluarkan suatu entitas untuk mendapatkan manfaat saat ini atau masa mendatang dari barang dan jasa yang telah didapat.

\section{Akuntansi Pertanggungjawaban}

Akuntansi pertanggungjawaban adalah suatu sistem akuntansi yang memberikan tanggungjawab terhadap suatu pusat pertanggungjawaban yang pada akhirnya akan diukur untuk menentukan kinerja pusat yang bersangkutan.

Menurut Mulyadi (1997:184) syarat-syarat untuk dapat mengatakan akuntansi pertanggungjawaban dilaksanakan dengan baik sebagai berikut:

\section{Struktur organisasi}

Struktur organisasi menggambarkan aliran tugas, wewenang dan tanggung jawab dengan jelas sehingga tidak ditemukan kerancuan dalam bekerja.

\section{Anggaran biaya}

Anggaran biaya yang disusun untuk tiap manajemen sesuai struktur organisasi, anggaran ini nantinya dijadikan biaya standar yang akan dijadikan target pada perusahaan.

3. Pemisahan biaya antara biaya terkendali dan tidak terkendali

Pemisahan biaya antara biaya terkendali dan tidak terkendali membantu manajer 
pusat pertanggungjawaban biaya dalam mengendalikan biaya.

\section{Sistem kode rekenening}

Sistem kode rekening mempermudah manajer untuk menelusur penyimpanganpenyimpangan biaya yang mungkin terjadi kaitannya dengan kewenangan pengendalian pusat pertanggungjawaban, selain itu mempermudah dalam penyusunan laporan keuangan perusahaan.

\section{Pelaporan biaya}

Pelaporan biaya kepada manajer yang bertanggung jawab untuk dievaluasi dan ditindak lanjuti atas penyimpangan yang terjadi.

Menurut Mulyadi (1997:186) karakteristik/unsur-unsur yang ada pada akuntansi pertanggungjawaban adalah sebagai berikut:

1. Identifikasi Tanggung Jawab

Akuntansi pertanggungjawaban mengklasifikasikan pusat-pusat pertanggungjawaban sebagai bagian yang ada di organisasi seperti departemen, tim project, tim produk, maupun individu.

2. Identifikasi standar kinerja

Standar kinerja dijadikan sasaran yang akan dikerjakan pusat pertanggungjawaban yang telah ditetapkan sebelumnya sehingga pedoman bekerja dapat mengarahkan para karyawan untuk mencapai target serta sasaran.

3. Penilaian kinerja

Kinerja manajer diukur dengan melakukan penilaian kinerja, baik secara finansial maupun nonfinansial. Penilaian kinerja secara finansial dilakukan dengan membandingkan realisasi dengan anggaran yang telah dijadikan biaya standar sebelumnya. Manajer hanya bertanggung jawab atas biaya yang ia kendalikan untuk dipengaruhi penggunaannya. Penilaian kinerja dapat dijadikan sebagai alat pengawasan manajer dalam mengendalikan pusat pertanggungjawaban.

4. Pemberian penghargaan atau hukuman Sistem pemberian penghargaan dan hukuman kepada manajer maupun karyawan dirancang untuk memacu dalam mengelola biaya untuk mencapai target biaya standar. Hasil penilaian kinerja dijadikan sebagai dasar untuk memberikan penghargaan atau hukuman.

\section{Penelitian Terdahulu}

Menurut Bhandari dkk. (2018), akuntansi pertanggungjawaban dapat dijadikan pengontrol aktivitas perusahaan karena penyimpangan yang terjadi dapat dilaporkan di awal sehingga perusahaan dapat mengambil tindakan korektif demi rencana masa depan. Pada penelitian ini disebutkan bahwa laporan pertanggungjawaban berisi perbandingan realisasi dan anggaran kinerja.

Menurut Dr. Adegbie dkk (2018), akuntansi pertanggungjawaban memiliki pengaruh positif signifikan terhadap produktivitas di perusahaan-perusahaan yang ada di Nigeria sehingga menambah nilai-nilai perusahaan. Menurut Fauzan (2017), akuntansi pertanggungjawaban yang baik dapat dilihat dari unsur utama, yaitu penetapan tanggung jawab dan wewenang, standar pengukuran kinerja, evaluasi kinerja, pemberian penghargaan dan pengharagaan. Menurut Haq dkk (2016), akuntansi pertanggungjawaban sebagai alat bantu manajemen dalam menilai kinerja bagian produksi mempunyai peran yang sangat penting dalam menilai kinerja dari pusat-pusat pertanggungjawaban. Menurut Andriana dkk (2015), keefektifan penerapan akuntansi pertanggungjawaban dapat dilihat dari pengaruh kinerja manajer pusat pertanggungjawaban sehingga kedua-nya menunjukkan hubungan yang kuat 


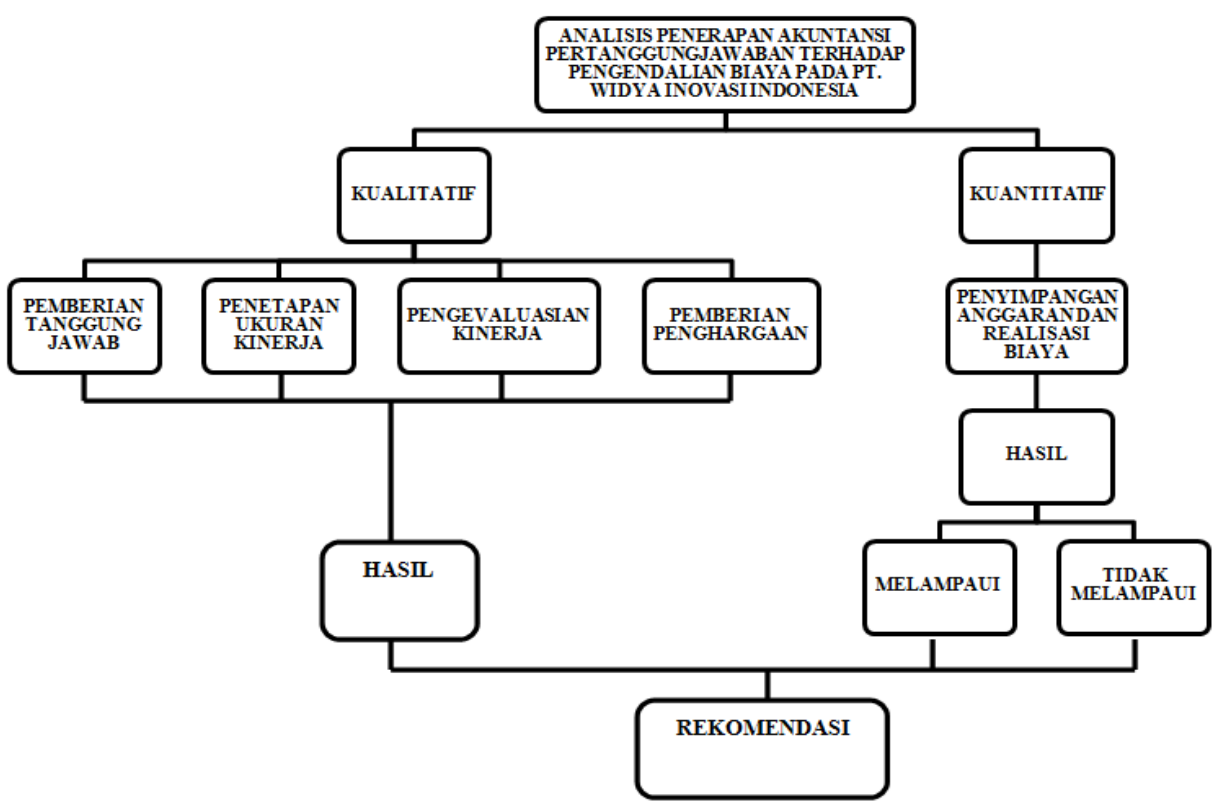

Gambar 1 Kerangka Penelitian

\section{METODE PENELITIAN}

\section{Jenis Penelitian}

Penelitian ini menggunakan pendekatan penelitian deskriptif dengan pendekatan kualitatif dan kuantitatif. Pendekatan kualitatif dengan melakukan analisis pada unsur-unsur dan persyaratan akuntansi pertanggungjawaban yang diterapkan PT WII. pendekatan kuantitatif menggunakan perbandingan anggaran dan realisasi biaya pada PT WII.

\section{Objek Penelitian}

Dalam penelitian ini objek penelitian menggunakan studi kasus di PT WII yang bergerak di bidang tekologi dan informasi. Penelitian yang dilakukan untuk meneliti penerapan akuntansi pertanggungjawaban pada PT WII.

\section{Tempat Dan Waktu Penelitian}

a. Tempat penelitian

Kantor PT WII.

b. Waktu penelitian

Periode : 4 Februari-28 Maret 2020

\section{Teknik Pengumpulan Data}

a. Observasi

Observasi dilakukan dengan cara mengamati kegiatan pada PT WII dengan berpartisipasi dalam beberapa kegiatan perusahaan sehingga dapat diketahui secara langsung penerapan akuntansi pertangungjawaban yang dilakukan pada PT WII.

b. Wawancara

Wawancara menghasilkan data primer berkaitan dengan sistem akuntansi pertanggungjawaban dengan bertanya kepada divisi finance dan human resource generalist di PT WII

c. Dokumentasi

Data yang dapat diperoleh dari dokumentasi, yaitu laporan keuangan pada tahun 2019 dan rencana anggaran biaya pada tahun 2019. Dokumentasi membantu penulis untuk mengkaji lebih dalam evaluasi akuntansi pertanggungjawaban di PT WII.

\section{Sumber Data}

a. Data Primer berasal dari wawancara dan dokumentasi. Data primer tersebut mencakup hasil wawancara 
terkait unsur-unsur dan syarat-syarat akuntansi pertanggungjawaban.

b. Data Sekunder, data yang diperoleh secara tidak langsung dari objek yang akan diteliti. Data ini berasal dari dokumentasi. Data sekunder mencakup laporan anggaran dan realisasi biaya PT WII tahun 2019.

\section{Instrumen Penelitian}

Instrumen penelitian berisi indikator-indikator pertanyaan yang mengarahkan penulis untuk mencari informasi yang berhubungan dengan akuntansi pertanggungjawaban

Tabel 2 Indikator Pertanyaan

\begin{tabular}{|c|c|c|c|c|}
\hline No. & Variabel & Subvariabel & Indikator Pertanyaan & Sumber \\
\hline \multirow[t]{4}{*}{1.} & $\begin{array}{l}\text { Akuntansi } \\
\text { Pertanggungja } \\
\text { waban }\end{array}$ & $\begin{array}{l}\text { Penetapan } \\
\text { tanggung jawab }\end{array}$ & $\begin{array}{l}\text { a. Struktur organisasi } \\
\text { b. Tugas dan wewenang } \\
\text { c. Pusat pertanggungjawaban }\end{array}$ & $\begin{array}{l}\text { (Mulyadi, 1997); } \\
\text { (Anthony dan } \\
\text { Govindarajan, } \\
\text { 2005) }\end{array}$ \\
\hline & & $\begin{array}{l}\text { Penentuan } \\
\text { ukuran kinerja }\end{array}$ & $\begin{array}{l}\text { a. Standar kinerja secara finansial } \\
\text { maupun nonfinansial } \\
\text { b. Target tiap divisi } \\
\text { c. Penyusunan standar } \\
\end{array}$ & $\begin{array}{l}\text { (Mulyadi, 1997); } \\
\text { (Wibowo; 2010) }\end{array}$ \\
\hline & & $\begin{array}{l}\text { Penilaian } \\
\text { Kinerja }\end{array}$ & $\begin{array}{l}\text { a. Evaluasi pada standar kinerja } \\
\text { b. Evaluasi pada target program dan } \\
\text { kegiatan } \\
\text { c. Penilaian kinerja secara finansial } \\
\text { maupun nonfinansial } \\
\text { d. Periode evaluasi/penilaian kinerja } \\
\text { e. Laporan kinerja }\end{array}$ & $\begin{array}{l}\text { (Mulyadi, 1997); } \\
\text { (Anthony dan } \\
\text { Govindarajan, } \\
\text { 2005) }\end{array}$ \\
\hline & & $\begin{array}{l}\text { Pemberian } \\
\text { Penghargaan }\end{array}$ & $\begin{array}{l}\text { a. Pemberian penghargaan secara } \\
\text { finansial maupun nonfinansial } \\
\text { b. Pemberian hukuman secara } \\
\text { finansial maupun nonfinansial } \\
\text { c. Manfaat pemberian penghargaan }\end{array}$ & (Mulyadi, 1997) \\
\hline 2. & $\begin{array}{l}\text { Pengendalian } \\
\text { Biaya }\end{array}$ & & $\begin{array}{l}\text { a. Pemisahan antara biaya terkendali } \\
\text { dan tidak terkendali } \\
\text { b. Sistem kode rekening } \\
\text { c. Anggaran biaya } \\
\text { d. Penyusunan anggaran } \\
\text { e. Penyimpangan anggaran } \\
\text { f. Laporan pertanggungjawaban } \\
\text { biaya } \\
\text { g. Efisiensi biaya dalam perusahaan }\end{array}$ & $\begin{array}{l}\text { (Mulyadi, 1997); } \\
\text { (Supriyono, 2001) }\end{array}$ \\
\hline
\end{tabular}

\section{Teknik Analisis Data}

Metode penelitian tidak berupa pengujian suatu hipotesis, tetapi mengungkapkan suatu fenomena dengan menganalisis aspek-aspek yang relevan dengan fenomena tersebut, kemudian dinilai dan ditarik kesimpulan sebagai jawaban atas permasalahan yang terjadi. Teknik analisis data yang digunakan adalah metode statistik deskriptif kuantitatif dan deskriptif kualitatif. 
Teknik analisis data kualitatif yang digunakan dalam menganalisis 4 indikator dalam penerapan akuntansi pertanggungjawaban oleh peneliti adalah teknik analisis data model Miles and Hiberman (2007:16) yaitu:

1. Data Reduction (Reduksi Data)

2. Data Display (Penyajian Data)

3. Conclusion : Drawing / Verification (Penarikan Kesimpulan dan Verifikasi)

Teknik analisis data kuantitatif yang digunakan dalam menyimpulkan penelitian ini adalah dengan membandingkan anggaran biaya yang dijadikan biaya standar perusahaan dengan realisasi biaya yang berupa biaya sesungguhnya yang terjadi pada perusahaan. Perbandingan ini menghasilkan nilai berupa prosentase realisasi biaya terhadap anggaran biaya. Perbandingan anggaran dan realisasi biaya yang dilakukan perbulan menggunakan rumus :

$$
\frac{\text { Realisasi Biaya }}{\text { Anggaran Biaya }} \times 100
$$

\section{Gambar 2 Rumus Perbandingan Realisasi dan Anggaran Biaya}

Jika hasil perbandingan menghasilkan keterangan melampaui, menandakan biaya tersebut tidak menguntungkan/unfavorable karena realisasi melebihi anggaran biaya yang sudah ditetapkan. Tetapi jika hasil perbandingan menghasilkan keterangan tidak melampaui, menandakan biaya tersebut menguntungkan/favorable karena realisasi tidak melebihi anggaran biaya.

Tabel 2 Hasil Perbandingan Rencana Dan Realisasi Anggaran Biaya

\begin{tabular}{|c|c|}
\hline Hasil & Keterangan \\
\hline$>100 \%$ & Melampaui \\
\hline$<100 \%$ & Tidak Melampaui \\
\hline
\end{tabular}

\section{HASIL DAN PEMBAHASAN}

\section{Penerapan Akuntansi Pertanggung- jawaban Terhadap Pengendalian Biaya} Akuntansi pertanggungjawaban mempunyai fungsi sebagai alat pengendalian biaya. Akuntansi pertanggungjawaban menggunakan bagian-bagian perusahaan untuk membentuk unit-unit kerja yang disebut pusat pertanggungjawaban. Akuntansi pertanggungjawaban menghubungkan biaya dengan bagian peru-sahaan dimana biaya tersebut dikeluarkan oleh manajer yang bertanggungjawab atas pusat pertanggungjawaban biaya tersebut.

Analisis penerapan akuntansi pertanggungjawaban pada PT WII dengan membandingkan teori-teori yang telah ada dengan data-data langsung yang terdapat pada PT WII. Berdasarkan unsur-unsur akuntansi pertanggungjawaban, PT WII telah menerapkan dengan cukup baik unsur-unsur akuntansi pertanggungjawaban.

1. Unsur Penetapan Tanggung Jawab

Perusahaan telah menyusun struktur organisasi berupa bentuk piramid. Aliran tugas PT WII mengalir dari manajemen yang lebih atas ke yang lebih bawah, sedangkan aliran tanggung jawab mengalir dari arah sebaliknya. Pelaksanaan tanggung jawab dan wewenang para karyawan sudah dijalankan dengan baik sesuai arahan dari manajer di atasnya.

2. Unsur Penetapan Ukuran Kinerja

Setiap pusat pertanggungjawaban menetapkan target-target operasional dan anggaran. Kemudian dibuat perbandingan realisasi dengan anggaran tersebut untuk melihat apakah pengendalian biaya telah berjalan dengan baik. Selain itu, ditentukan ukuran kinerja secara nonfinansial berupa Standar Operasional Perusahaan (SOP) serta tugas dan tanggung jawab divisi untuk mengendalikan kerja karyawan agar terarah dan meminimalisir kesalahan ketika bekerja.

\section{Unsur Evaluasi/Penilaian Kinerja}

Evaluasi secara finansial dilakukan tiap bulan dengan membandingkan realisasi dengan anggaran biaya. Selain itu evaluasi kinerja pada PT WII 
dilakukan secara nonfinansial melalui beberapa metode, yaitu metode top down, umpan balik 360 dan 2 on 1 . Evaluasi dengan beberapa metode ini dilakukan bersamaan pada akhir tahun dan dilaporkan dalam bentuk naratif.

\section{Unsur Pemberian Penghargaan}

PT WII menggunakan hasil skor evaluasi kinerja untuk menentukan besaran kenaikan gaji serta tambahan tunjangan kinerja pada setiap karyawan. Selain itu, terdapat aturan mengenai pemberian hukuman menuntut karyawan untuk bekerja secara professional di bawah naungan perusahaan. Hal ini dilakukan dapat memunculkan motivasi serta sikap kehati-hatian ketika bekerja.

Berdasarkan syarat-syarat akuntansi pertanggungjawaban, PT WII belum memadai dalam memenuhi syarat-syarat akuntansi pertanggungjawaban.

\section{Struktur Organisasi}

Struktur organisasi sudah disusun dan dapat dilihat tugas dan wewenang serta tanggung jawab secara jelas.

\section{Anggaran}

Anggaran telah disusun secara bottom up yang menunjukkan semua bagian yang bersinggungan langsung dengan kebutuhan operasional perusahaan ikut serta dalam penyusunan anggaran.

\section{Pemisahan Biaya}

Perusahaan belum melakukan pemisahan antara biaya terkendali dan biaya tidak terkendali. Dengan tidak adanya pemisahan antara biaya terkendali dan tidak terkendali, perusahaan tidak dapat melakukan pengendalian biaya dengan maksimal karena semua biaya menjadi tanggung jawab manajer pusat biaya. Anggaran yang telah disusun juga tidak dapat mengukur kinerja manajer karena laporan pertanggungjawaban tidak mencerminkan besaran biaya yang menjadi tanggung jawab manajer pusat biaya.

\section{Kode Rekening}

Pencatatan kode rekening yang belum tepat mempengaruhi kualitas akuntansi pertanggungjawaban. Sistem kode rekening yang belum tepat mengakibatkan kerumitan dalam penelusuran tanggung jawab manajer yang mengatur biaya apabila terjadi penyimpangan biaya yang cukup signifikan. Sistem kode rekening sebaiknya disusun berdasarkan tingkatan manajemen sesuai dengan yang tertera pada struktur organisasi.

\section{Laporan Pertanggungjawaban}

Penyusunan laporan pertanggungjawaban secara rutin sebulan satu kali dapat digunakan sebagai alat pengawasan pimpinan tertinggi perusahaan. Laporan pertanggung-jawaban berisi perbandingan realisasi dan anggaran, analisis varians untuk mengetahui apakah hasil perbandingan tersebut menguntungkan (favorable) atau tidak menguntungkan (unfavorable).

Hubungan akuntansi pertanggungjawaban yang baik dengan pengendalian biaya dapat dilihat dari anggaran biaya perusahaan. Anggaran biaya menjadi informasi akuntansi pertanggungjawaban dan menjadi tolak ukur pengendalian biaya. Dengan menganalisis anggaran biaya dengan biaya sesungguhnya, dapat diketahui seberapa efisien pengendalian biaya dapat dilakukan perusahaan.

\section{Tabel 3 Hasil Perbandingan Biaya PT WII 2019}

\begin{tabular}{|l|rr|rr|rr|l|}
\hline \multicolumn{1}{|c|}{ Bulan } & \multicolumn{2}{|c|}{ Anggaran } & \multicolumn{2}{c|}{ Realisasi } & \multicolumn{2}{c|}{ Varians } & Keterangan \\
\hline Januari & $\mathrm{Rp}$ & 201.101 .700 & $\mathrm{Rp}$ & 58.827 .510 & $\mathrm{Rp}$ & 142.274 .190 & Favorable \\
\hline Februari & $\mathrm{Rp}$ & 206.178 .700 & $\mathrm{Rp}$ & 46.743 .474 & $\mathrm{Rp}$ & 159.435 .226 & Favorable \\
\hline Maret & $\mathrm{Rp}$ & 191.262 .700 & $\mathrm{Rp}$ & 130.176 .468 & $\mathrm{Rp}$ & 61.086 .232 & Favorable \\
\hline
\end{tabular}




\begin{tabular}{|l|ll|lr|rr|l|}
\hline April & $\mathrm{Rp}$ & 186.355 .700 & $\mathrm{Rp}$ & 87.165 .718 & $\mathrm{Rp}$ & 99.189 .982 & Favorable \\
\hline Mei & $\mathrm{Rp}$ & 201.458 .700 & $\mathrm{Rp}$ & 218.799 .670 & $\mathrm{Rp}$ & 17.340 .970 & Unfavorable \\
\hline Juni & $\mathrm{Rp}$ & 196.571 .700 & $\mathrm{Rp}$ & 59.219 .127 & $\mathrm{Rp}$ & 137.352 .573 & Favorable \\
\hline Juli & $\mathrm{Rp}$ & 191.695 .700 & $\mathrm{Rp}$ & 117.968 .988 & $\mathrm{Rp}$ & 73.726 .712 & Favorable \\
\hline Agustus & $\mathrm{Rp}$ & 191.831 .700 & $\mathrm{Rp}$ & 79.532 .974 & $\mathrm{Rp}$ & 112.298 .726 & Favorable \\
\hline September & $\mathrm{Rp}$ & 191.981 .700 & $\mathrm{Rp}$ & 44.696 .041 & $\mathrm{Rp}$ & 147.285 .659 & Favorable \\
\hline Oktober & $\mathrm{Rp}$ & 192.146 .850 & $\mathrm{Rp}$ & 106.440 .695 & $\mathrm{Rp}$ & 85.706 .155 & Favorable \\
\hline November & $\mathrm{Rp}$ & 184.748 .700 & $\mathrm{Rp}$ & 54.869 .406 & $\mathrm{Rp}$ & 129.879 .294 & Favorable \\
\hline Desember & $\mathrm{Rp}$ & 182.527 .700 & $\mathrm{Rp}$ & 197.013 .827 & $\mathrm{Rp}$ & 14.486 .127 & Unfavorable \\
\hline
\end{tabular}

Sumber : PT WII

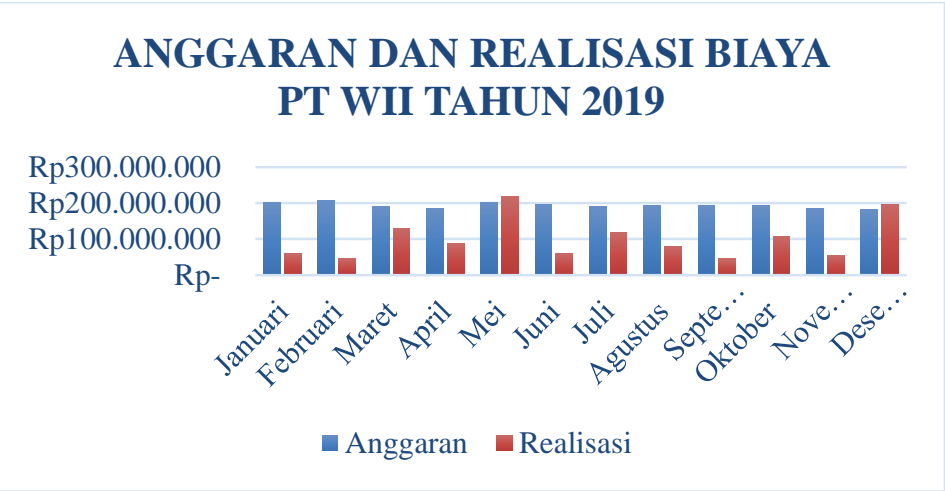

Gambar 3 Grafik Batang Perbandingan Biaya PT WII 2019

Berdasarkan pembahasan mengenai anggaran dan realisasi biaya PT WII tahun 2019, masih terdapat 2 bulan yang menunjukkan biaya sesungguhnya perusahaan melebihi anggaran/biaya standar perusahaan. Hal tersebut menunjukkan pengendalian biaya pada PT WII masih belum efisien.

\section{Hambatan Penerapan Akuntansi Pertanggungjawaban}

Hambatan PT WII dalam penerapan akuntansi pertanggungjawaban selama tahun 2019 :

1. Hambatan pada unsur penetapan tanggung jawab tidak ditemukan dikarenakan struktur organisasi sudah jelas dalam menggambarkan aliran tugas dan wewenang serta tanggung jawab setiap bagian. Hal tersebut menyebabkan tidak adanya seseorang yang salah dalam mengerjakan tugas dan tanggung jawabnya sehingga kesalahan pekerjaan dapat dihindari demi memenuhi tujuan perusahaan untuk mengendalikan biaya.

2. Hambatan dalam menerapkan penetapan standar kinerja pada PT WII adalah tidak adanya batasan skor dalam penilaian kinerja secara nonfinansial, hal itu menyebabkan perusahaan kesulitan dalam menentukan range keberhasilan karyawan beserta manajer. Meskipun begitu perusahaan tetap mempunyai standar yang dijadikan pedoman bekerja baik secara finansial maupun nonfinansial. Standar secara finansial berupa anggaran tiap divisi, sedangkan standar nonfinansial berupa Standar Operasional Perusahaan (SOP).

3. Hambatan dalam penerapan penilaian kinerja pada PT WII adalah tidak adanya tindak lanjut berupa rekomendasi atas penyimpangan yang telah terjadi. Laporan pertanggung- 
jawaban telah berisi laporan realisasi terhadap anggaran biaya beserta analisis penyimpangannya, tetapi laporan hanya sebatas sampai analisis penyimpangan tanpa tindak lanjut berupa rekomendasi dalam laporan tersebut. Hal tersebut menyebabkan perusahaan mengalami permasalahan terhadap pengendalian biaya.

4. Hambatan dalam menerapkan unsur terakhir pada PT WII adalah kurang jelasnya perhitungan tunjangan kinerja kepada karyawan. Meskipun perhitungan tunjangan kinerja berdasarkan hasil skor penilaian kinerja, tetapi karena tidak adanya slip gaji yang menjelaskan perhitungan secara jelas terkait tunjangan kinerja menyebabkan tercipta asumsi bahwa perusahaan belum tegas dalam penerapan pemberian penghargaan dan hukuman.

Beberapa hambatan yang telah dipaparkan diatas sedikitnya mempengaruhi kinerja manajer kaitannya dalam mengendalikan biaya perusahaan. Meskipun terdapat anggaran biaya yang dijadikan standar kinerja finansial maupun dijadikan biaya standar perusahaan yang harus dicapai, tetapi jika realisasi biaya yang mengalami penyimpangan tidak ditindaklanjuti dengan baik akan memberikan kesalahan yang berkelanjutan pada perusahaan. Kurang jelasnya perhitungan penghargaan dalam bentuk tunjangan kinerja juga menyebabkan biaya yang dikeluarkan bisa jadi tidak menunjukkan seberapa banyak kinerja karyawan.

Hambatan tidak hanya ada pada penerapan unsur akuntansi pertanggungjawaban saja tetapi juga terdapat pada persyaratan akuntansi pertanggungjawaban. Hambatan tersebut terdapat pada pemisahan biaya terkendali dan tidak terkendali, penerapan sistem kode rekening serta laporan pertanggungjawaban.

1. Tidak ada hambatan dalam penerapan struktur organisasi karena sudah jelas menggambarkan tugas dan wewenang setiap bagian perusahaan.
2. Tidak ada hambatan dalam penyu-sunan anggaran dikarenakan peru-sahaan sudah menggunakan azas partisipasi. Semua bagian yang ber-singgugan langsung dengan kegiatan operasional perusahaan sudah menunjukkan partisipasinya dalam penyusunan anggaran.

3. Perusahaan belum melakukan pemisahan biaya terkendali dan tidak terkendali padahal pemisahan tersebut memudahkan manajemen dapat mengetahui siapa yang bertanggungjawab atas penggunaan biaya selama satu periode. Selain itu dapat lebih mudah untuk mengendalikan pengeluaran biaya sehingga tidak terjadi overbudget.

4. Kode rekening pada PT WII belum dicatat untuk setiap pengeluaran sesuai departemen atau bagian, semua perkiraan kode rekening masih bersifat umum untuk semua bagian. Kode rekening yang ada belum mencerminkan kewenangan pusat pertanggungjawaban sehingga belum memberikan informasi mengenai tempat terjadinya biaya dan manajer yang bertanggungjawab atas terjadinya biaya tersebut.

5. Laporan pertanggungjawaban PT WII sudah menyajikan laporan realisasi dan anggaran biaya beserta analisisnya, tetapi belum melakukan tindak lanjut atas penyimpangan-penyimpangan yang terjadi.

Hambatan perusahaan dalam menerapkan persyaratan akuntansi pertanggungjawaban sedikitnya memberi dampak dalam pengendalian biaya. Pengendalian biaya hubungannya dengan akuntansi pertanggungjawaban dapat dilihat dari anggaran dan realisasi biaya perusahaan. Belum adanya pemisahan biaya terkendali dan tidak terkendali menyebabkan semua biaya yang terjadi pada perusahaan merupakan tanggung jawab manajer pusat biaya.

Untuk meningkatkan kinerja perusahaan di masa datang, perusahaan 
harus menerapkan akuntansi pertanggungjawaban secara baik dalam kaitannya dengan pengendalian biaya.

1. PT WII menerapkan sistem kode rekening yang sesuai dengan akuntansi pertanggungjawaban yang semestinya sehingga perusahaan dapat bekerja secara efektif dan efisien dalam kaitannya dengan pengendalian biaya. PT WII telah melakukan pengkodean rekening untuk setiap transaksi perkiraan. Kode rekening tersebut mengidentifikasi jenis perkiraan untuk aktiva, hutang, pendapatan, dan biaya. Kode rekening pada PT WII terdiri dari 4 digit yang dijelaskan sebagai berikut.

1) 1 digit pertama merupakan kelompok perkiraan

2) 1 digit berikutnya merupakan kelompok sub perkiraan

3) 2 digit terakhir merupakan penomoran

Tabel 4 Hasil Perbandingan Biaya PT WII 2019

\begin{tabular}{|c|c|}
\hline $\begin{array}{c}\text { Kode Kel. } \\
\text { Perkiraan }\end{array}$ & Kelompok Rekening \\
\hline 1 & Aset \\
\hline 2 & Kewajiban \\
\hline 3 & Pendapatan \\
\hline 4 & Beban \\
\hline 5 & $\begin{array}{r}\text { Pendapatan/Beban Lain- } \\
\text { Lain }\end{array}$ \\
\hline 6 & \\
\hline
\end{tabular}

Menurut Mulyadi (1997:198) pemberian kode dapat dilaksanakan salah satunya dengan metode kelompok. Kode kelompok mempunyai sifat-sifat sebagai berikut.

1) Posisi masing-masing angka mempunyai arti, di mana angka yang paling kiri merupakan kode golongan perkiraan dan angka yang paling kanan adalah kode jenis rekening.
2) Setiap kode dalam golongan perkiraan terdiri dari angka-angka yang sudah ditetapkan dan angka tersebut mewakili jenis rekening.

\section{5 a b c dd}

a) 1 digit awal berupa angka 5 merupakan kelompok rekening biaya.

b) 1 digit setelahnya berupa "a" merupakan pusat pertanggungjawaban direksi.

c) 1 digit setelahnya berupa "b" merupakan pusat pertanggungjawaban departemen.

d) 1 digit setelahnya berupa "c" merupakan pusat pertanggungjawaban bagian.

e) 2 digit terakhir berupa "dd" merupakan jenis/penomoran biaya.

2. Pemisahan biaya terkendali dan tidak terkendali.

Dilakukan pemisahan antara biaya terkendali dan tidak terkendali dalam pelaporan biaya sehingga penyebab penyimpangan dapat ditelusur dengan jelas dan dapat ditindak lanjuti lebih tegas.

Pedoman untuk menetapkan apakah suatu biaya dapat dibebankan menjadi tanggung jawab manajer pusat pertanggungjawaban menurut Mulyadi (1997:164) adalah sebagai berikut.

a. Jika seorang manajer memiliki wewenang, baik dalam perolehan maupun penggunaan jasa, ia harus dibebani dengan biaya tersebut. Seorang manajer dapat mempengaruhi jumlah suatu biaya juka ia memiliki wewenang dalam memperoleh dan menggunakan jasa.

b. Jika seorang manajer dapat dengan signifikan mempengaruhi jumlah biaya tertentu melalui tindakannya sendiri, ia dapat dibebani dengan biaya tersebut. Manajer mungkin dapat secara signifikan mempunyai pengaruh dalam pemakaian biaya.

c. Meskipun seorang manajer tidak dapat secara signifikan mem- 
pengaruhi jumlah biaya tertentu melalui tindakannya sendiri, ia juga dapat dibebani suatu biaya jika manajemen puncak menghendaki ia untuk menaruh perhatian pada biaya tersebut.

3. Membuat format target kinerja berupa indikator untuk tiap divisi sehingga perusahaan dapat dimudahkan dalam penilaian kinerja.

4. Laporan pertanggungjawaban yang telah dilakukan secara rutin sebaiknya juga diberikan rekomendasi atas penyimpangan-penyimpangan yang tidak menguntungkan sebagai dasar untuk pengambilan keputusan.

5. Penerapan reward and punishment system yang lebih tegas dengan memberikan bonus yang jelas pembagiannya baik untuk manajer maupun anggota tim serta memberikan sanksi yang tegas dan kelas bagi yang tidak berprestasi.

\section{KESIMPULAN DAN SARAN}

Berdasarkan hasil dari penelitian mengenai penerapan akuntansi pertanggungjawaban terhadap pengendalian biaya pada PT WII, maka dapat ditarik kesimpulan sebagai berikut.

1. Berdasarkan unsur-unsur akuntansi pertanggungjawaban, PT WII telah menerapkan dengan cukup baik unsurunsur akuntansi pertanggungjawaban sedangkan berdasarkan syarat-syarat akuntansi pertanggungjawaban, PT WII belum memadai dalam memenuhi syarat-syarat akuntansi pertanggungjawaban pada pemisahan antara biaya terkendali dan tidak terkendali serta penyusunan sistem kode rekening yang belum tepat. Hubungan antara akuntansi pertanggungjawaban dengan pengen-dalian biaya dapat dilihat dari anggaran biaya perusahaan. Anggaran dan realisasi biaya PT WII tahun 2019 masih terdapat 2 bulan yang menunjukkan biaya sesungguhnya perusahaan melebihi anggaran atau biaya standar perusahaan. Hal tersebut menunjukkan penerapan akuntansi pertanggungjawaban yang belum memenuhi beberapa persyaratan berdampak pada pengendalian biaya pada PT WII yang masih belum efisien.

2. Hambatan PT WII dalam menerapkan setiap unsur akuntansi pertanggungjawaban kaitannya dengan pengendalian biaya terletak pada tidak adanya batasan skor dalam standar kinerja secara nonfinansial sehingga perusahaan kesulitan dalam menen-tukan range keberhasilan karyawan beserta manajer. Selain itu, tidak adanya tindak lanjut berupa rekomendasi terkait penyimpangan biaya yang pernah terjadi sehingga di bulan beikutnya masih terdapat penyimpangan biaya yang cukup besar. Selain itu, tidak adanya slip gaji yang menjelaskan perhitungan secara jelas terkait tunjangan kinerja menyebabkan tercipta asumsi bahwa perusahaan belum tegas dalam penerapan pemberian penghargaan dan hukuman.

Saran yang dapat diberikan kepada perusahaan untuk meningkatkan kinerja perusahaan di masa mendatang, yaitu memperbaiki sistem kode rekening sehingga perusahaan dapat bekeja secara efektif dan efisien, pemisahan biaya terkendali sehingga penyebab penyimpangan mudah ditelusur, memperbarui indikator standar kinerja serta format target kinerja sehingga mempermudah dalam penilaian kinerja, menindaklanjuti laporan pertanggungjawaban serta memberikan rekomendasi terkait pengambilan keputusan atas penyimpangan yang terjadi, dan mempertegas pemberian penghargaan. 


\section{DAFTAR PUSTAKA}

Adegbie, Festus, F., Olaoye, \& Samuel, A. (2018). Application Of Responsibility Accounting To ProductivityEvaluation In The Nigerian Quoted Companies. Journal of Advance Research in Business Management and Accounting, 20-21.

Anthony, R., \& Govindarajan, V. (2005). Sistem Pengendalian Manajemen Jilid 2. Jakarta: Salemba Empat.

Badan Ekonomi Kreatif, \& Badan Pusat Statistik. (2017). Profil Usaha/Perusahaan 16 Subsektor Ekraf Berdasarkan Sensus Ekonomi 2016 (SE2016). Jakarta: Badan Pusat Statistik.

Badan Pusat Statistik. (2018). Statistik Perusahaan Informasi Dan Komunikasi. Jakarta: Badan Pusat Statistik.

Balqis, K. (2015). Peranan Akuntansi Pertanggungjawaban Dalam Kinerja Manajer Pusat Pertanggungjawaban (Studi Kasus Pada Produk Manufaktur PT. Pindad (Persero).

Bhandari, A. S., \& Kaur, S. J. (2018). Responsibility Accounting: An Innovative Technique Of Accounting System. International Journal of Management, Technology And Engineering, 4-7.

Daljono. (2009). Akuntansi Biaya : Penentuan Harga Pokok \& Pengendalian. Semarang: Badan Penerbit Universitas Diponegoro.

Hansen, D. R., \& Mowen, M. M. (2009). Akuntansi Manajerial. Jakarta: Salemba Empat.

Haq, A., \& Christyaningrum, A. (2016). Penerapan Akuntansi Pertanggungjawaban Sebagai Alat Bantu Manajemen Dalam Menilai Kinerja Bagian Produksi PT. Cemani Toka Periode 2013-2014.

Hariadi, B. (1992). Akuntansi Manajemen Suatu Pengantar Edisi 1. Yogyakarta: BPFE Yogyakarta.
Kurniawan, F. (2016). Analisis Penerapan Akuntansi Pertanggungjawaban Pada Titik Fokus Kamera Tahun 2016. Yogyakarta: Univesitas Negeri Yogyakarta.

Miles, M., \& Huberman, A. (2007). Analisis Data Kualitatif: Buku Sumber Tentang Metode-metode Baru. Jakarta: UI Press.

Mulyadi. (1997). Akuntansi manajemen: konsep, manfaat, dan rekayasa. Yogyakarta: Sekolah Tinggi Ilmu Ekonomi YKPN.

Nazir, M. (2011). Metode Penelitian. Bogor: Penerbit Ghalia Indonesia.

Rudianto. (2006). Akuntansi Manajemen. Jakarta: PT Grasindo.

Sekaran, U. (2006). Metodologi Penelitian Untuk Bisnis 1 Edisi Keempat. Jakarta: Penerbit Salemba Empat.

Sugiyono. (2016). Metode Penelitian Kuantitatif Kualitatif $d n \quad R \& B$. Bandung: Alfabeta.

Supriyono. (2001). Akuntansi Manajemen Edisi Ketiga. Yogyakarta: BPFE UGM.

Wibowo. (2010). Manajemen Kinerja. Jakarta: Rajawali Press. 